\title{
Article
}

\section{Low Ozone Concentrations Differentially Affect the Structural and Functional Features of Non-Activated and Activated Fibroblasts In Vitro}

\author{
Barbara Cisterna ${ }^{1}$, Manuela Costanzo ${ }^{1}$, Maria Assunta Lacavalla ${ }^{1}$, Mirco Galiè ${ }^{1}$ (D), Osvaldo Angelini ${ }^{2}$, \\ Gabriele Tabaracci $^{2}$ and Manuela Malatesta ${ }^{1, *(D)}$
}

1 Department of Neurosciences, Biomedicine and Movement Sciences, Anatomy and Histology Section, University of Verona, Strada Le Grazie 8, I-37134 Verona, Italy; barbara.cisterna@univr.it (B.C.); manuela.costanzo@univr.it (M.C.); mariaassunta.lacavalla@univr.it (M.A.L.); mirco.galie@univr.it (M.G.)

2 San Rocco Clinic, Via Monsignor G.V. Moreni 95, I-25018 Montichari, Italy; osva.ange@virgilio.it (O.A.); tabaracci@sanrocco.net (G.T.)

* Correspondence: manuela.malatesta@univr.it

check for updates

Citation: Cisterna, B.; Costanzo, M.; Lacavalla, M.A.; Galiè, M.; Angelini, O.; Tabaracci, G.; Malatesta, M. Low Ozone Concentrations Differentially Affect the Structural and Functional Features of Non-Activated and Activated Fibroblasts In Vitro. Int. J. Mol. Sci. 2021, 22, 10133. https:// doi.org/10.3390/ijms221810133

Academic Editor: Wojciech Bal

Received: 29 August 2021

Accepted: 17 September 2021

Published: 20 September 2021

Publisher's Note: MDPI stays neutral with regard to jurisdictional claims in published maps and institutional affiliations.

Copyright: (c) 2021 by the authors. Licensee MDPI, Basel, Switzerland. This article is an open access article distributed under the terms and conditions of the Creative Commons Attribution (CC BY) license (https:/ / creativecommons.org/licenses/by/ $4.0 /)$.

\begin{abstract}
Oxygen-ozone $\left(\mathrm{O}_{2}-\mathrm{O}_{3}\right)$ therapy is increasingly applied as a complementary/adjuvant treatment for several diseases; however, the biological mechanisms accounting for the efficacy of low $\mathrm{O}_{3}$ concentrations need further investigations to understand the possibly multiple effects on the different cell types. In this work, we focused our attention on fibroblasts as ubiquitous connective cells playing roles in the body architecture, in the homeostasis of tissue-resident cells, and in many physiological and pathological processes. Using an established human fibroblast cell line as an in vitro model, we adopted a multimodal approach to explore a panel of cell structural and functional features, combining light and electron microscopy, Western blot analysis, real-time quantitative polymerase chain reaction, and multiplex assays for cytokines. The administration of $\mathrm{O}_{2}-\mathrm{O}_{3}$ gas mixtures induced multiple effects on fibroblasts, depending on their activation state: in non-activated fibroblasts, $\mathrm{O}_{3}$ stimulated proliferation, formation of cell surface protrusions, antioxidant response, and IL- 6 and TGF- $\beta 1$ secretion, while in LPS-activated fibroblasts, $\mathrm{O}_{3}$ stimulated only antioxidant response and cytokines secretion. Therefore, the low $\mathrm{O}_{3}$ concentrations used in this study induced activation-like responses in non-activated fibroblasts, whereas in already activated fibroblasts, the cell protective capability was potentiated.
\end{abstract}

Keywords: oxygen-ozone therapy; cell proliferation; cell surface protrusions; nuclear factor erythroid 2-related factor 2 (Nrf2); heme oxygenase 1 (Hmox1) gene; interleukin-6; transforming growth factor (TGF)- $\beta 1$; fluorescence microscopy; scanning electron microscopy; real-time quantitative polymerase chain reaction (RT-qPCR)

\section{Introduction}

In the last decades, the medical use of gaseous ozone $\left(\mathrm{O}_{3}\right)$ has been progressively increasing as a complementary/adjuvant treatment for several diseases [1-4]. $\mathrm{O}_{3}$ is a highly unstable gas rapidly decomposing to oxygen, and it is applied for therapeutic purposes as $\mathrm{O}_{2}-\mathrm{O}_{3}$ mixtures with low $\mathrm{O}_{3}$ concentrations. In fact, the mild oxidative stress induced by low doses of $\mathrm{O}_{3}$ activates the nuclear factor erythroid 2-related factor 2 (Nrf2)-mediated Keap1-dependent pathway, which, in turn, stimulates gene expression of antioxidant response elements (ARE) [5-7]. In fact, the exposure to low $\mathrm{O}_{3}$ concentrations promotes an antioxidant cytoprotective response [8,9], which is consistent with the principle of hormesis, i.e., "the beneficial effect of a low-level exposure to an agent that is harmful at high levels" [10].

Despite the wide application of $\mathrm{O}_{2}-\mathrm{O}_{3}$ administration in clinical practice, the biological mechanisms accounting for the therapeutic efficacy of $\mathrm{O}_{3}$ have been only partially unveiled, 
and further investigations are necessary to understand the multiple effects of this gas on the different cell types in tissues and organs. As an example, appropriate $\mathrm{O}_{2}-\mathrm{O}_{3}$ gas mixtures proved to exert an adipogenic effect in human adipose-derived adult stem cells [11] and to reduce lipid loss in explanted adipose tissue [6]. In addition, it has recently been demonstrated that, besides activating an antioxidant response through the Nrf2-ARE pathway, $\mathrm{O}_{2}-\mathrm{O}_{3}$ gas mixtures are able to modulate cytokine secretion in T lymphocytes [7].

In the present work, we focused our attention on the fibroblast as a primary target of $\mathrm{O}_{2}-\mathrm{O}_{3}$ therapy. In fact, it is worth noting that, whatever the administration route (intramuscular, intra- and peri-articular or subcutaneous injection, topical bagging, rectal or vaginal insufflation, autohemotherapy), $\mathrm{O}_{2}-\mathrm{O}_{3}$ mixtures inevitably act on fibroblasts; actually, these are ubiquitous cells playing multiple roles in the architecture of organs and the whole body, in the homeostasis of tissue-resident cells, and in many physiological (e.g., wound healing) and pathological processes, such as autoimmunity, fibrosis, and cancer [12]. It is therefore likely to expect that fibroblasts may be involved in the pathways activated by $\mathrm{O}_{2}-\mathrm{O}_{3}$ administration and, in turn, in the therapeutic outcome.

An established human fibroblast cell line was used as a suitable in vitro model to study the response to $\mathrm{O}_{2}-\mathrm{O}_{3}$ treatment under strictly controlled experimental conditions. We investigated the structural and functional effects of low $\mathrm{O}_{3}$ concentrations on fibroblasts in non-activated and lipopolysaccharide (LPS)-activated state with the aim to analyze the response of these tissue-resident cells in a steady state or after the response to activating stimuli (as it happens following tissue injury and/or inflammation, when they are committed to restore homeostasis [13]). We used gas mixtures with 10,20 , and $30 \mu \mathrm{g} \mathrm{O} / \mathrm{mL}$ $\mathrm{O}_{2}$ - concentrations usually applied in clinical practice. In order to explore a panel of structural and functional cell features, a multimodal approach was adopted, by combining light (bright field and fluorescence) microscopy, scanning electron microscopy (SEM), Western blot analysis, real-time quantitative polymerase chain reaction (RT-qPCR), and multiplex assays for cytokines.

\section{Results}

\subsection{Cytotoxicity}

At $24 \mathrm{~h}$ after the gas exposure, the percentage of dead cells (estimated by the LDH release) was similar $(<6 \%)$ in all samples of non-activated fibroblasts, irrespective of the treatment $(p=0.77$, Figure 1). Similarly, no difference in cell death was found among the LPS-activated samples $(p=0.11$; Figure 1$)$. LPS-activated control samples showed a significantly lower value $(<2 \% ; p=0.02)$ in comparison with the non-activated controls.

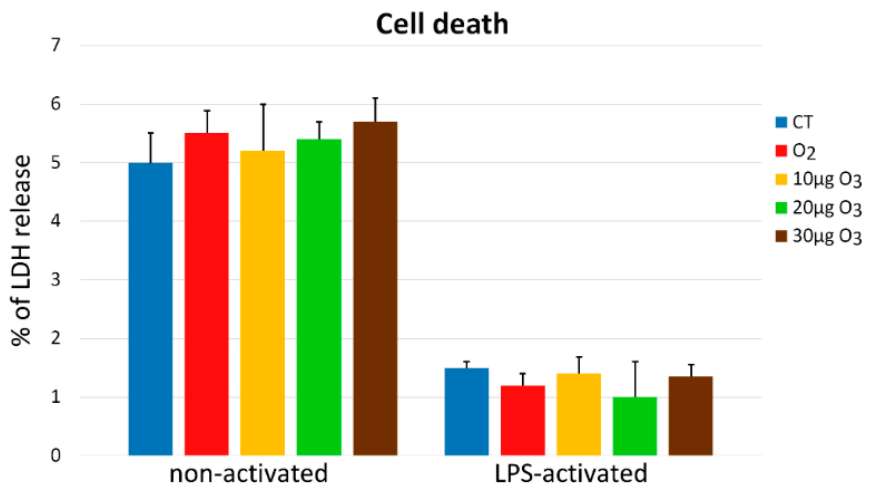

Figure 1. Percentages of dead cells (mean values \pm SE) $24 \mathrm{~h}$ after the treatment (one experiment in triplicate). No significant difference was found among the samples of either group. CT-untreated control. 


\subsection{S-Phase Evaluation}

Under a conventional fluorescence microscope, bromodeoxyuridine (BrdU)-positive fibroblasts appeared labelled in green, while DNA was counterstained in blue (Figure 2a-c). At $24 \mathrm{~h}$ after the gas treatment, significant difference in the percentage of BrdU-positive cells was found in non-activated fibroblasts $(p=0.01)$; post-hoc analysis revealed that only cells exposed to $10 \mu \mathrm{g} \mathrm{O}_{3}$ showed a significantly increased proliferation rate in comparison with the controls $(p=0.04)$ (Figure 2d). In LPS-activated fibroblasts, the exposure to $\mathrm{O}_{2}$ or $\mathrm{O}_{3}$ did not alter the percentage of BrdU-positive cells $(p=0.52)$ (Figure 2d). LPS-activated control samples showed a significantly lower cell proliferation in comparison with the non-activated controls $(p<0.001)$.

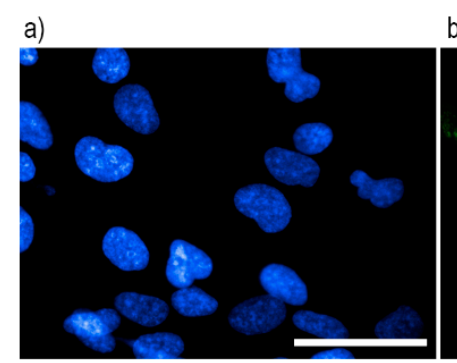

b)
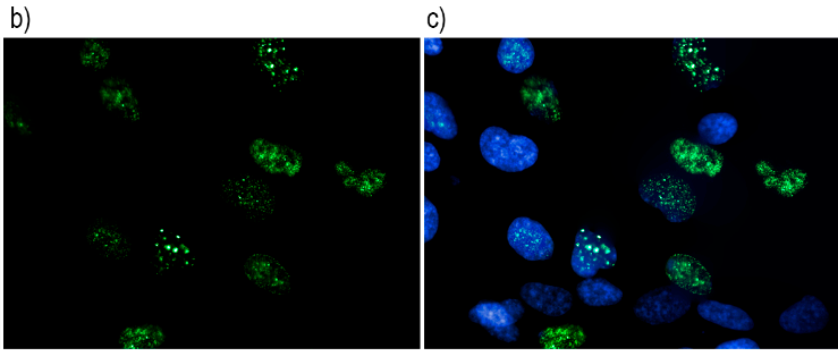

d)

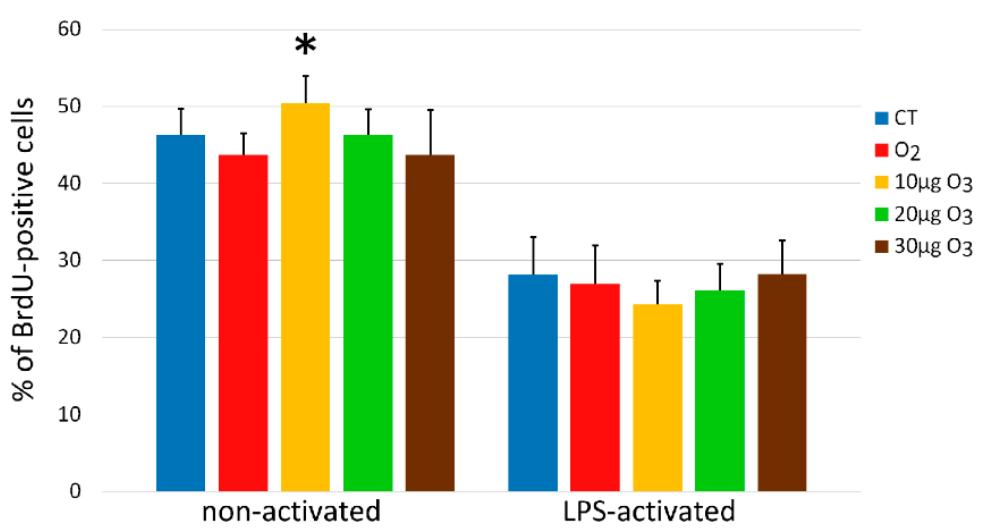

Figure 2. (a-c) Representative fluorescence microscopy images of fibroblasts stained for DNA with Hoechst 33342 (blue) (a), immunolabelled for BrdU (green) (b), and merged (c). Bar, $100 \mu \mathrm{m}$. (d) Mean values \pm SE of percentages of BrdU-positive cells $24 \mathrm{~h}$ after the treatment (one experiment in triplicate). The asterisk $\left({ }^{*}\right)$ indicates significant difference in comparison with the respective control (CT).

\subsection{Wound Healing Assay}

The wound healing assay (representative images in Figure 3a,b) showed similar migration rates in all samples of both non-activated (Figure S1) and LPS-activated (Figure S2) fibroblasts $2 \mathrm{~h}(p=0.21$ and $p=0.33$, respectively) and $6 \mathrm{~h}(p=0.06$ and $p=0.76$, respectively) (Figure $3 c, d$ ) after gas exposure. After $24 \mathrm{~h}$, the wound was completely healed in all samples (not shown). 
a)

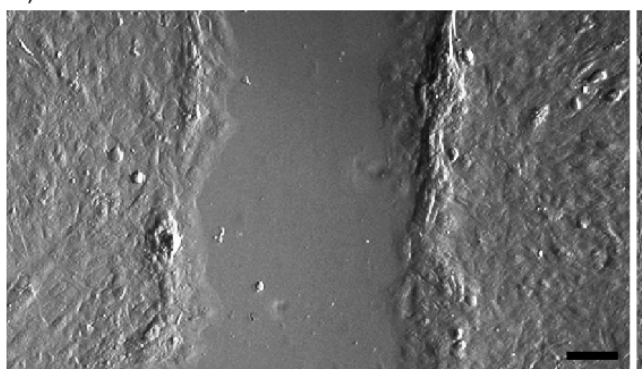

b)

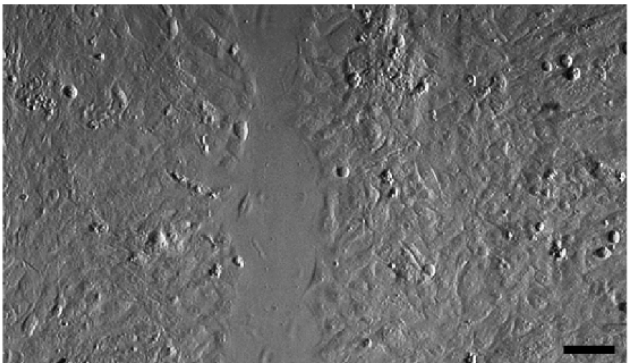

c)

Non-activated fibroblasts

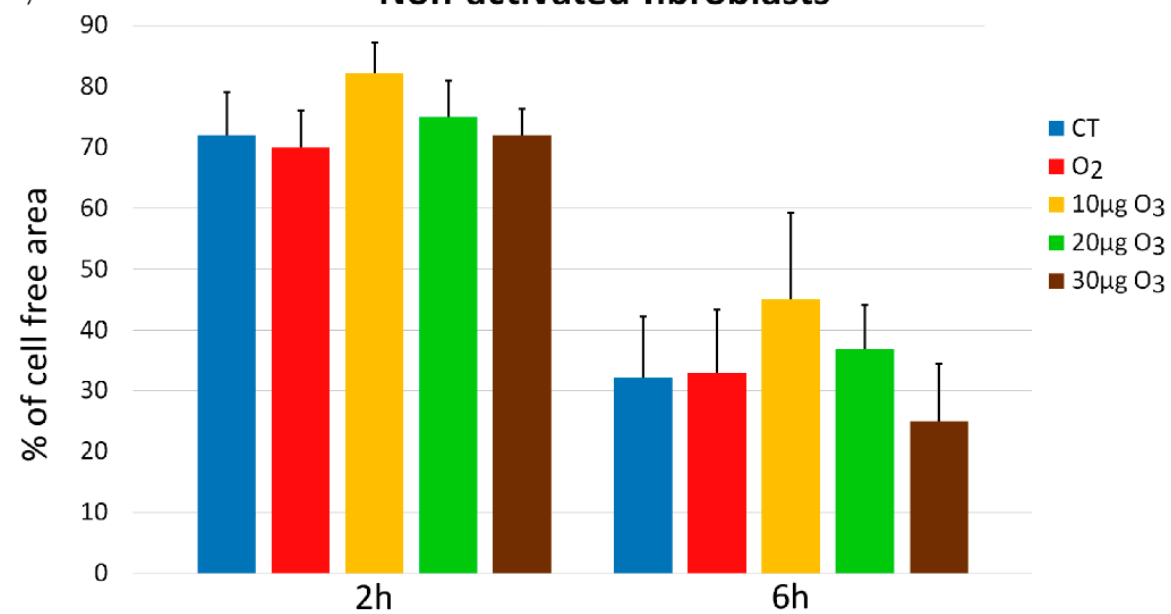

d)

LPS-activated fibroblasts

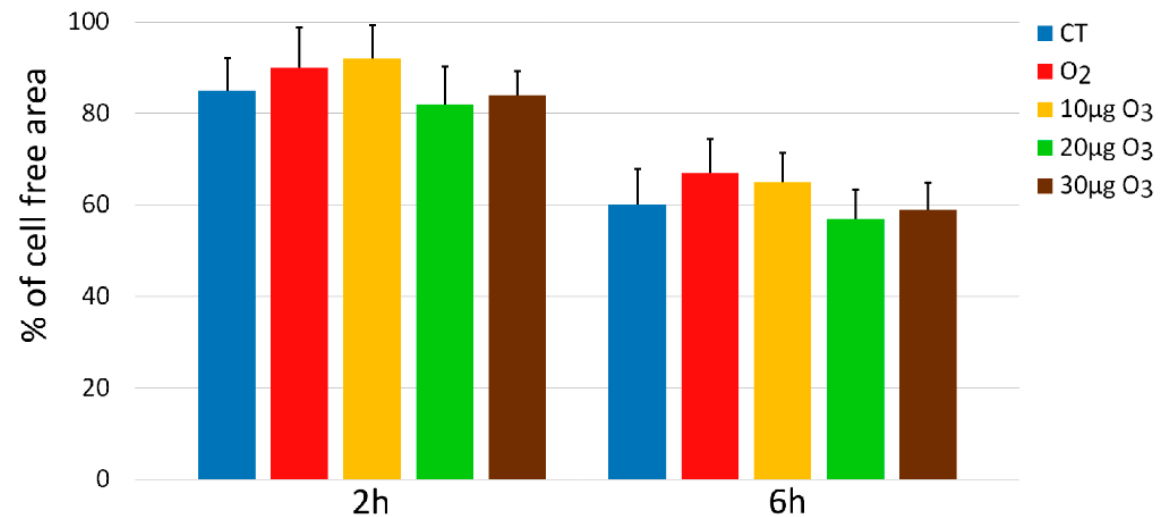

Figure 3. (a,b) Representative inverted microscope images of fibroblasts at $2 \mathrm{~h}(\mathbf{a})$ and $6 \mathrm{~h}(\mathbf{b})$ of the wound healing assay. Bars, $200 \mu \mathrm{m}$. (c,d) Means \pm SE of percentages of cell-free areas of control (CT), $\mathrm{O}_{2}$ - and $\mathrm{O}_{3}$-treated non-activated (c) and LPS-activated (d) fibroblasts at $2 \mathrm{~h}$ and $6 \mathrm{~h}$ of the wound healing assay (three experiments). No statistical difference was found for both non-activated and LPS-activated samples.

\subsection{Scanning Electron Microscopy}

In non-activated condition, control and $\mathrm{O}_{2}$-treated fibroblasts appeared flattened and irregularly polygonal in shape, with scarce filamentous protrusions of the cell surface (Figure $4 \mathrm{a}, \mathrm{b}$ ). $\mathrm{O}_{3}$-treated fibroblasts maintained the polygonal shape but showed an increase in the surface projections (Figure 4c-e). In LPS-activated condition, all samples showed evident surface protrusions (Figure $4 \mathrm{f}-\mathrm{j}$ ). 


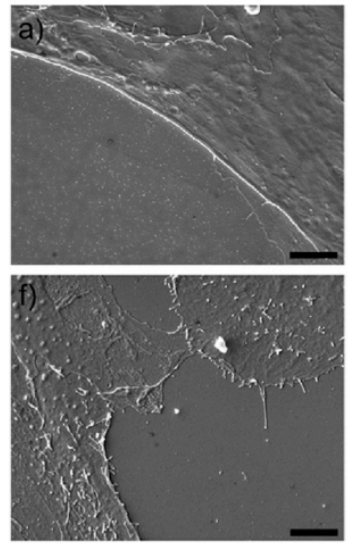

k)
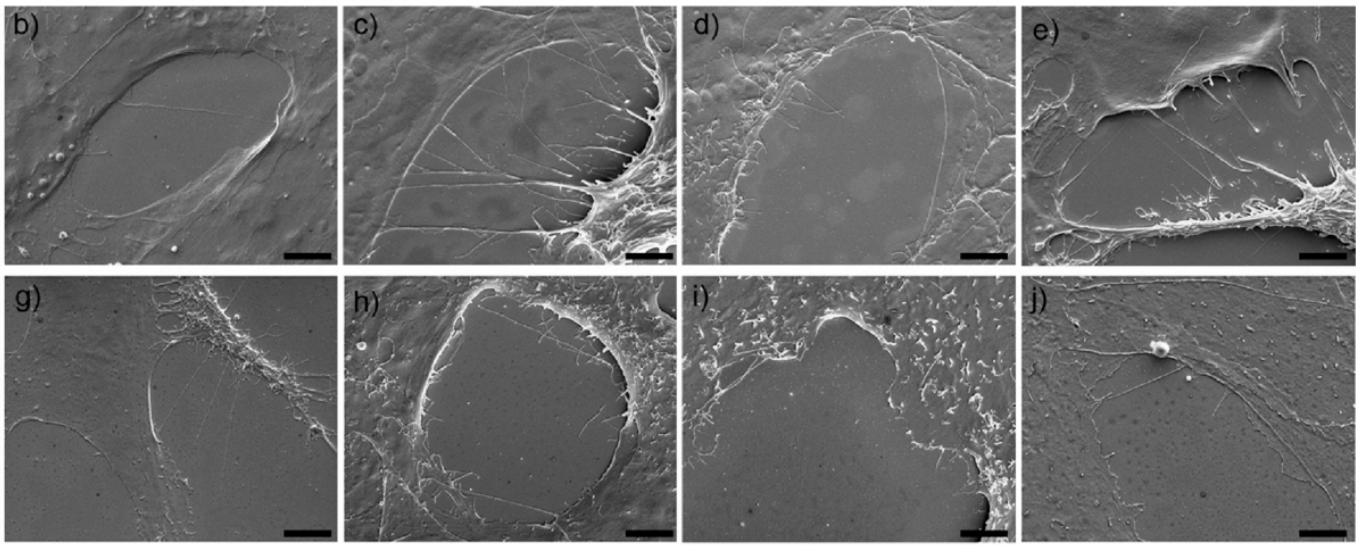

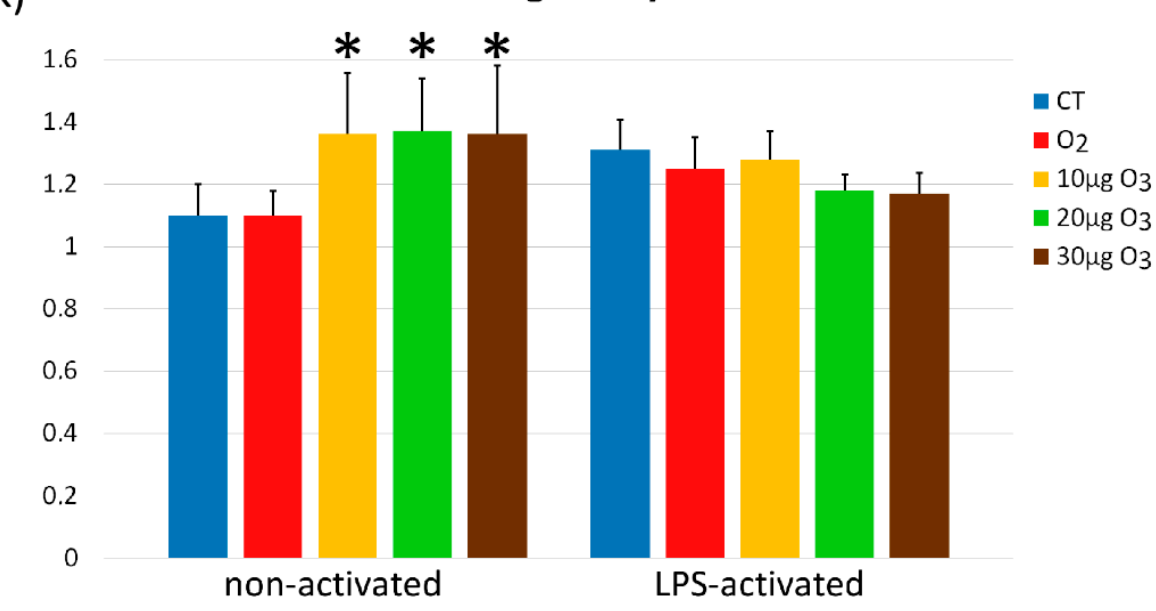

Figure 4. Scanning electron micrographs of non-activated $(\mathbf{a}-\mathbf{e})$ and LPS-activated $(\mathbf{f}-\mathbf{j})$ fibroblasts in control $(\mathbf{a}, \mathbf{f})$ and $24 \mathrm{~h}$ after exposure to $\mathrm{O}_{2}(\mathbf{b}, \mathbf{g}), 10 \mu \mathrm{g} \mathrm{O}(\mathbf{c}, \mathbf{h}), 20 \mu \mathrm{g} \mathrm{O}(\mathbf{d}, \mathbf{i})$, and $30 \mu \mathrm{g} \mathrm{O}(\mathbf{e}, \mathbf{j})$. Bars, $10 \mu \mathrm{m}$. (k) Means $\pm \mathrm{SE}$ of the cell irregularity index at $24 \mathrm{~h}$ after the treatment in non-activated or LPS-activated fibroblasts (one experiment). Significant increase in the cell irregularity index was found in non-activated fibroblasts after $\mathrm{O}_{3}$ treatments $\left(^{*}\right)$.

Quantitative evaluation of the surface irregularities showed significant differences in non-activated fibroblasts $(p=0.006)$, confirming that the protrusions of $\mathrm{O}_{3}$-treated samples significantly increased $(p<0.01)$ in comparison with control and $\mathrm{O}_{2}$-treated samples (Figure $4 \mathrm{k}$ ). No significant difference in surface irregularity was found among LPS-activated samples ( $p=0.09$ ) (Figure $4 \mathrm{k}$ ).

In LPS-activated condition, control samples had a significant increase in surface protrusions in comparison with the non-activated controls $(p=0.03)$.

\subsection{Western Blot Analysis}

In non-activated fibroblasts, the total amount of Nrf2 protein was similar in all samples (Figure 5a). In LPS-activated fibroblasts, the Nrf2 protein content showed an evident increase in the samples treated with $20 \mu \mathrm{g} \mathrm{O}_{3}$ and $30 \mu \mathrm{g} \mathrm{O}$ in comparison with the control (Figure 5b). 
a)
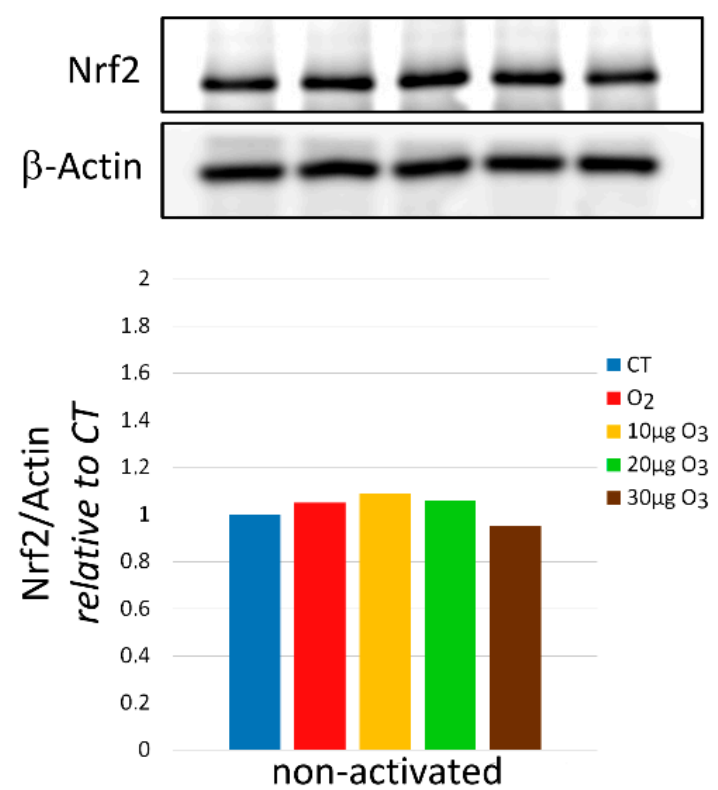

b)
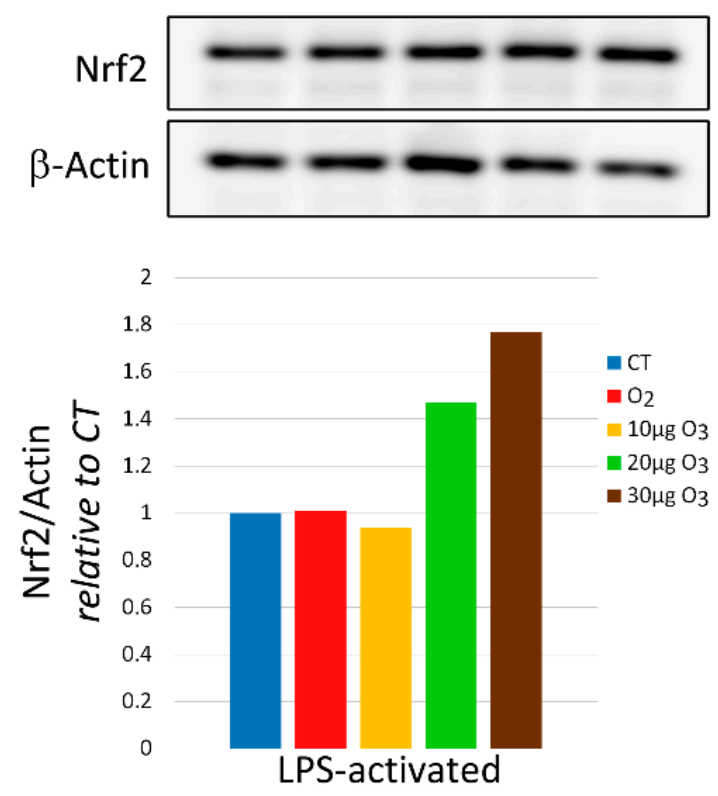

Figure 5. Western blot of Nrf2 protein at $20 \mathrm{~min}$ after treatment of non- activated (a) and activated (b) fibroblasts (one experiment in duplicate). Data were normalized to the level of a housekeeping protein (actin) and expressed as in proportion to the levels in control (CT) sample.

\subsection{Real-Time Quantitative Polymerase Chain Reaction}

In non-activated fibroblasts, the one-way ANOVA test demonstrated significantly different Heme oxygenase 1 (Hmox1) gene expression $(p=0.03)$ among samples; in particular, $20 \mu \mathrm{g} \mathrm{O}_{3}$-treated fibroblasts showed values significantly higher in comparison with control $(p=0.002)$ (Figure 6a). On the other hand, no significant linear trend was found $(p=0.09)$. In LPS-activated fibroblasts, the one-way ANOVA test showed no significant difference $(p=0.07)$ among samples (Figure $6 \mathrm{~b})$, but the test for linear trend demonstrated a dose-dependent trend $(p=0.03)$.

a)

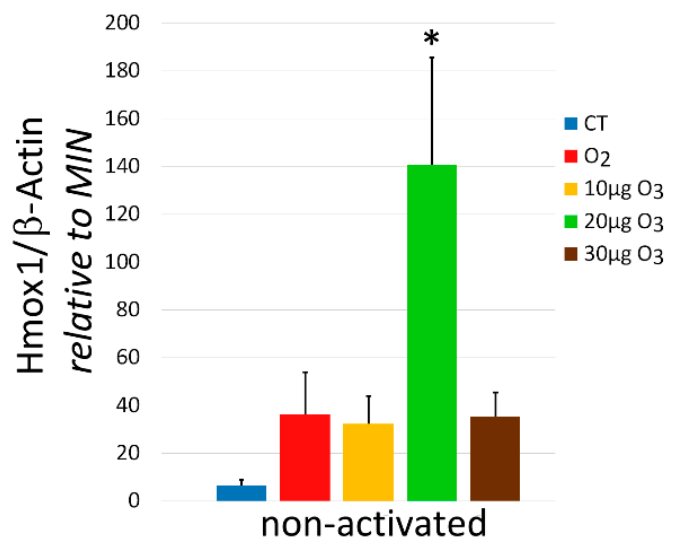

b)

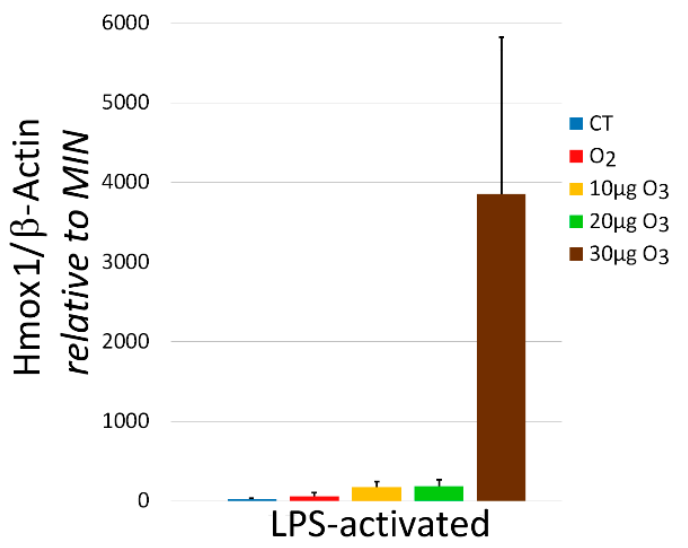

Figure 6. Hmox1 gene expression (means \pm SE) in non-activated (a) and LPS-activated (b) fibroblasts at $24 \mathrm{~h}$ after treatment (one experiment in triplicate). Asterisk $\left(^{*}\right)$ indicates significant difference with control (CT).

\subsection{Interleukin-6 and Transforming Growth Factor- $\beta 1$ Secretion}

In the non-activated condition, a significant difference was found in the amount of interleukin (IL)-6 secreted into the medium $(p=0.03)$; in particular, a significantly 
higher value was found in $10 \mu \mathrm{g} \mathrm{O}_{3}$-treated samples in comparison with all other samples $(p<0.05)$ (Figure 7). Significant difference was found also in the LPS-activated state $(p=0.004)$, where $\mathrm{O}_{3}$-treated samples secreted a significantly higher amount of IL-6 in comparison with control and $\mathrm{O}_{2}$-treated samples $(p<0.05)$.

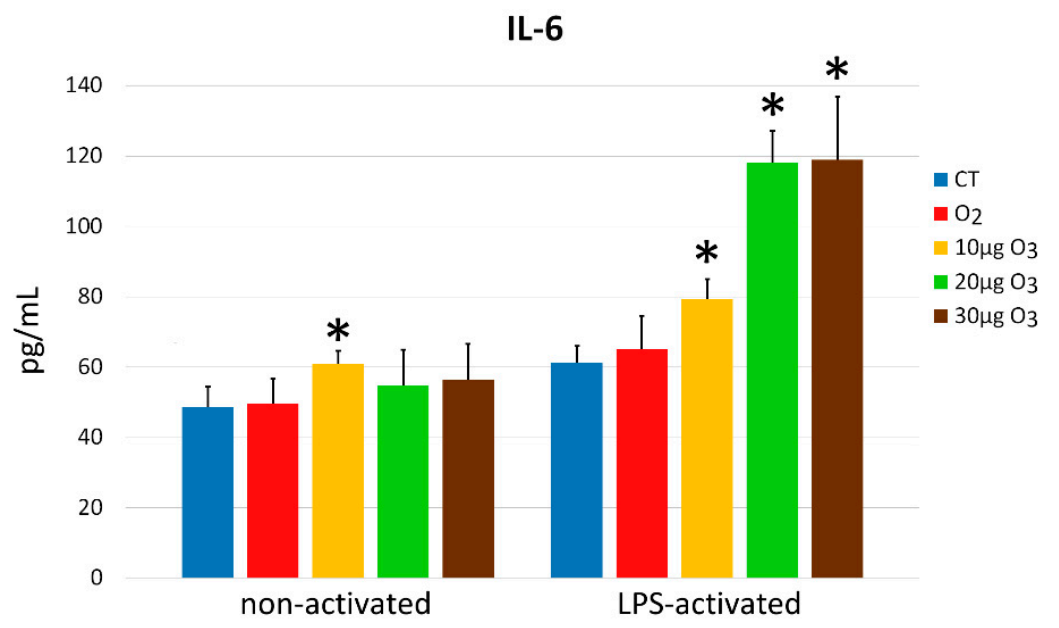

Figure 7. IL- 6 amounts (mean values \pm SE) detected in the medium of non-activated and LPSactivated cell samples $24 \mathrm{~h}$ after gas treatment (two experiments in duplicate). Asterisks $\left(^{*}\right)$ indicate significant differences from the respective controls (CT).

Moreover, LPS-activated control fibroblasts secreted significantly higher IL-6 amounts in comparison with non-activated control samples $(p=0.02)$ (Figure 7).

In the non-activated condition, a significant difference was found in the amount of transforming growth factor (TGF)- $\beta 1$ secreted into the medium $(p=0.01)$; in detail, a significantly higher value was found in $10 \mu \mathrm{g} \mathrm{O} \mathrm{O}_{3}$-treated samples in comparison with all other samples $(p<0.05)$ (Figure 8$)$. Similarly, significant difference was found in LPSactivated fibroblasts $(p<0.001)$, where the treatment with $10 \mu \mathrm{g} \mathrm{O}_{3}$ induced a significant increase in secreted TGF- $\beta 1$ in comparison with the other samples $(p<0.05)$, while the value in $30 \mu \mathrm{g} \mathrm{O}_{3}$-treated samples was below the detection limit.

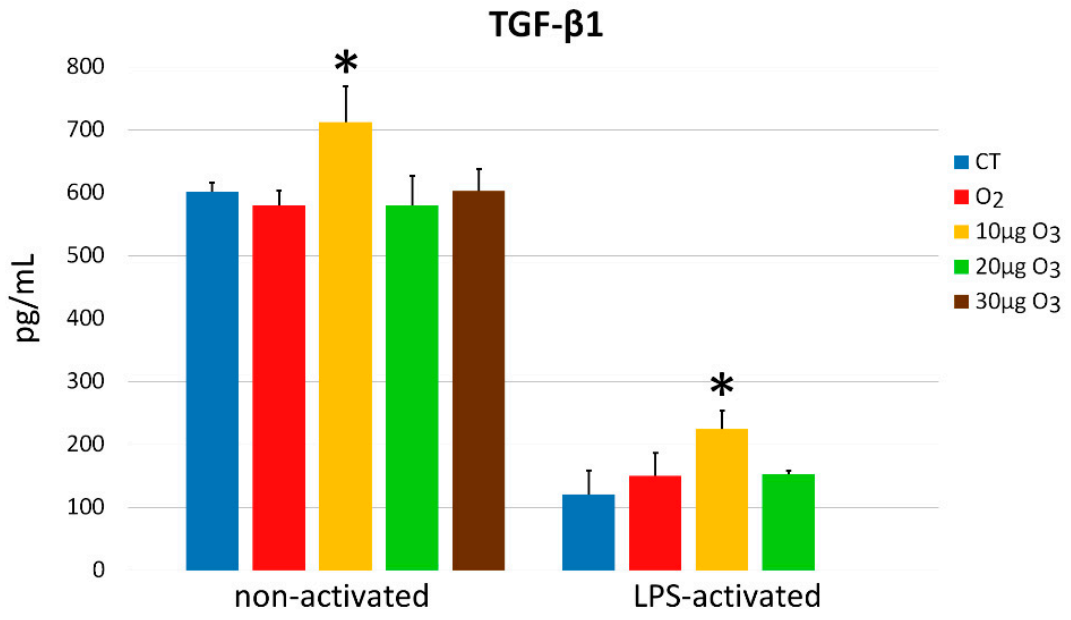

Figure 8. TGF- $\beta 1$ amounts (mean values $\pm \mathrm{SE}$ ) detected in the medium of non-activated and LPSactivated cell samples $24 \mathrm{~h}$ after gas treatment (two experiments in duplicate). In LPS-activated condition, the value of $30 \mu \mathrm{g} \mathrm{O}$-treated samples was below the detection limit. Asterisks ${ }^{*}$ ) indicate significant differences from the respective controls (CT). 
In addition, LPS-activated fibroblasts secreted significantly lower amounts of TGF- $\beta 1$ than non-activated control samples $(p=0.03)$ (Figure 8).

\section{Discussion}

In the present investigation, we evaluated the effects of the exposure to $\mathrm{O}_{2}-\mathrm{O}_{3}$ mixtures at low $\mathrm{O}_{3}$ concentrations on the structural and functional features of fibroblasts as a cell type ubiquitously distributed in body tissues. Being primarily responsible for the deposition and degradation of the extracellular matrix, fibroblasts play a key role in tissue remodeling [14] and wound healing [12] and are also involved in the immune response and, more generally, in the maintenance of tissue homeostasis [13]. The molecular and cellular effects of low $\mathrm{O}_{3}$ concentrations were investigated in both non-activated and LPS-activated fibroblasts, with the aim of getting information on the possibly differential response due to the cell functional state.

LDH assay showed that the exposure to any of the gas mixtures used did not induce significant cytotoxicity compared with the controls, in both non-activated and LPS-activated fibroblasts, consistent with previous data on other cell types $[6,7,11,15,16]$. The LDH values were lower for the LPS-treated than for the non-activated samples: this is likely due to the activated state itself, as it has been demonstrated that pro-survival mechanisms are stimulated in activated fibroblasts when these cells are committed to tissue repair [17].

Based on the evaluation of BrdU-positive S-phase cells, non-activated fibroblasts proved to be stimulated by the exposure to $10 \mu \mathrm{g} \mathrm{O}_{3}$, suggesting that the eustress induced by this mild concentration may promote cell growth, which is especially advantageous in the post-injury tissue repair $[18,19]$. Accordingly, non-activated fibroblasts treated with $10 \mu \mathrm{g} \mathrm{O}_{3}$ showed a tendency $(p=0.06)$ to be more efficient than the other samples in the wound healing assay, thus accounting for the observed positive effects of oxygen-ozone therapy on wound healing [20,21].

The proliferation rate of LPS-activated fibroblasts was unaffected by the exposure to any gas, but a significantly lower proliferation was found in LPS-activated fibroblasts in comparison with the non-activated ones. This finding may be also related to the activated state of the cells: consistent with the results in the present investigation, a decreased proliferation rate (without an increase in the LDH release) has already been reported in lung fibroblasts submitted to LPS treatment [22,23].

As already recalled, fibroblasts are involved in wound healing and mediate the formation and remodeling of connective and epithelial tissues [24-26]. Migrating fibroblasts are motile cells characterized by superficial cellular protrusions, such as lamellipodia and filopodia [27]; in addition, filamentous projections are formed to remodel the collagen-rich extracellular matrix during wound healing [28]. Under our experimental conditions, surface protrusions were scarce in control and $\mathrm{O}_{2}$-treated non-activated fibroblasts, but they evidently increased after $\mathrm{O}_{3}$ exposure. It is worth noting that small local changes in the amount of reactive oxygen species (ROS), as induced by mild ozonation [15], may stimulate the polymerization of cytoskeletal actin [29-31] that is essential to form cell protrusions and promote adhesion [32,33]. However, the wound healing assay showed that the $\mathrm{O}_{3}$-induced increase in the surface processes was not paralleled by a higher migration rate, consistent with previous evidence that $\mathrm{O}_{3}$ exposure does not affect the cell migration capability [34].

On the other hand, $\mathrm{O}_{3}$ did not affect surface protrusions in LPS-activated fibroblasts, whose control samples showed similar amounts of these membrane processes as the $\mathrm{O}_{3}$-treated non-activated fibroblasts. This is consistent with the finding that cultured fibroblasts treated with LPS increase their ROS production [35-37], which in turn affects the organization of cytoskeletal proteins [29-31]. It can therefore be inferred that the low $\mathrm{O}_{3}$ concentrations tested in the present study are able to induce activation-like changes of the cell membrane in non-activated fibroblasts but do not affect already LPS-activated fibroblasts, thus avoiding their overstimulation and the possible scarring of the extracellular matrix [28]. 
It is known that the administration of low $\mathrm{O}_{3}$ concentrations is able to restore impaired Nrf2 pathways in many pathological conditions [38-44], thus inducing a cytoprotective response accounting for the therapeutic potential of $\mathrm{O}_{3}$. The mechanism relies on the stabilization of Nrf2 that mediates an antioxidant response by the Keap1/Nrf2 dependent pathway [5]: ozonation prevents Keap1-mediated degradation of Nrf2 and promotes its translocation to the nucleus [5,7]), where it activates the expression of ARE-driven genes [5-7,16]. This enables an efficient and rapid transcription of antioxidant genes without requiring a de novo synthesis of Nrf2. Accordingly, in the present study, the total amount of Nrf2 protein was unchanged in non-activated fibroblasts, while the expression of Hmox1 (i.e., the marker gene for the mild- $\mathrm{O}_{3}$-induced antioxidant response) increased in samples treated with $20 \mu \mathrm{g} \mathrm{O}_{3}$, similarly as it was observed in nervous cells [16]. Genes involved in oxidative stress responses were found to be upregulated also in primary periodontal ligament fibroblasts treated with $\mathrm{O}_{3}$ ultrafine bubble water [45]. In LPSactivated fibroblasts, the Nrf2 protein increased in $20 \mu \mathrm{g} \mathrm{O}_{3}$ - and $30 \mu \mathrm{g} \mathrm{O}_{3}$-treated samples, probably due to the combined oxidative stress due to LPS and $\mathrm{O}_{3}$ exposure. Consistently, Hmox1 expression increased in a dose-dependent manner in $\mathrm{O}_{3}$-treated samples.

As stated above, fibroblasts are also involved in the regulation of the immune response (with complex and mutual interactions with the cells of the immune system) and are able to secrete different cytokines [46]. In particular, cultured fibroblasts secrete both IL-6 and TGF$\beta 1$ [47], as observed in our experimental model. Our data are also consistent with previous findings demonstrating that IL-6 secretion increases after LPS activation in vitro [48], while cell proliferation is inhibited in an autocrine pathway [22].

IL-6 exerts a pleiotropic effect on a broad spectrum of biological events and participates in the immune response as a potent pro-inflammatory cytokine involved in the acute inflammatory response; on the other hand, it also coordinates anti-inflammatory or repair-oriented activities essential for the resolution of inflammation [49]. In injured tissues, IL-6 is a major systemic alarm signal [50-52] involved in the activation of a variety of local and systemic host-defense mechanisms aimed at limiting tissue injury while stimulating angiogenesis, collagen production and organization, keratinocyte proliferation, and leukocyte infiltration [53-56]. The ability of low $\mathrm{O}_{3}$ concentrations to stimulate IL-6 secretion in fibroblasts is therefore compatible with the efficacy of $\mathrm{O}_{2}-\mathrm{O}_{3}$ therapy in wound healing and, more generally, in tissue repair [57-60]. In particular, low $\mathrm{O}_{3}$ concentrations seem to stimulate IL-6 secretion in LPS-activated fibroblasts more efficiently than in non-activated ones: this could be related to the activated state that makes the cells more responsive to stimuli. Interestingly, pre-treatment with low $\mathrm{O}_{3}$ concentrations proved to reduce IL-6 secretion in skin fibroblasts receiving doxorubicin, thus preventing the inflammatory effect of this potent cytotoxic drug [44]. Moreover, repeated and prolonged exposure of synovial fibroblasts isolated from patients affected by rheumatoid arthritis led to a decreased production of IL-6 [61]. The immunomodulation potential of $\mathrm{O}_{3}$ on fibroblasts therefore deserves detailed studies in view of targeted therapeutic approaches.

TGF- $\beta 1$ also plays important roles as a key cytokine in the wound healing process, where it acts bidirectionally [62], promoting the synthesis of various extracellular matrix proteins [63-67] and potentiating angiogenesis [68-70], while inhibiting extracellular matrix degradation [71] and inflammatory response [72,73]. TGF- $\beta 1$ has been also reported to enhance fibroblasts proliferation $[74,75]$. Therefore, its increased secretion in non-activated fibroblasts following $10 \mu \mathrm{O} \mathrm{O}_{3}$ treatment may be related to the higher proliferation rate found in this sample. On the other hand, LPS activation in vitro inhibits TGF- $\beta 1$ production [48], consistently with the very low amount of TGF- $\beta 1$ found in our LPS-activated fibroblasts. However, despite the inhibiting effect of LPS, $10 \mu \mathrm{g} \mathrm{O}$ 作 proved to be capable of increasing TGF- $\beta 1$ secretion also in LPS-activated fibroblasts; on the contrary, $20 \mu \mathrm{g} \mathrm{O}_{3}$ and $30 \mu \mathrm{g} \mathrm{O}$ treatments induce a higher stress and a stronger TGF- $\beta 1$ inhibition, likely due to the activation of the Nrf2/ARE-mediated antioxidant signaling [76-78]. The stimulating effect of low $\mathrm{O}_{3}$ concentrations on TGF- $\beta 1$ secretion observed in our in vitro model is con- 
sistent with the upregulation of this cytokine reported in cutaneous wounds undergoing accelerated repair following ozonated oil treatment $[79,80]$.

\section{Materials and Methods}

\subsection{Cell Culture and Treatment}

Human lung fibroblasts (WI-26, ATCC) were chosen for the present study as a suitable in vitro model previously used to investigate the effects of drugs on extracellular matrix deposition [81] and remodeling [82] as well as the response to various stimuli [83-85]. The fibroblasts were grown in Dulbecco's modified Eagle's medium supplemented with $10 \%(v / v)$ fetal bovine serum, $1 \%(w / v)$ glutamine, $100 \mathrm{U}$ of penicillin and $100 \mu \mathrm{g} / \mathrm{mL}$ streptomycin (all reagents were purchased from Gibco, Walthem, MA, USA) at $37^{\circ} \mathrm{C}$ in a $5 \% \mathrm{CO}_{2}$ humidified atmosphere.

The cells were treated with $\mathrm{O}_{2}-\mathrm{O}_{3}$ gas mixtures produced from medical-grade $\mathrm{O}_{2}$ by an OZO2 FUTURA apparatus (Alnitec, Cremosano, CR, Italy) that allows photometric real-time control of gas flow rate and $\mathrm{O}_{3}$ concentration. The concentrations of 10,20 , and $30 \mu \mathrm{g} \mathrm{O} 3 / \mathrm{mL} \mathrm{O}_{2}$ were chosen as these are usually administered in clinical practice and had been shown to be non-cytotoxic for different cultured cells $[7,11,15,16]$. The treatment with pure $\mathrm{O}_{2}$ was performed in order to discriminate the effect of $\mathrm{O}_{3}$ from $\mathrm{O}_{2}$ in the context of the $\mathrm{O}_{2}-\mathrm{O}_{3}$ gas mixtures. Controls consisted in cells submitted to the same handling but without exposure to gas.

The cells were trypsinized (0.25\% trypsin in PBS containing 0.05\% EDTA) (Gibco), when sub-confluent. For Western blot analysis and RT-qPCR, samples of $4 \times 10^{6}$ cells were suspended in $10 \mathrm{~mL}$ medium into a $20 \mathrm{~mL}$ polypropylene syringe, then $10 \mathrm{~mL}$ of gas was added into the syringe using a sterile filter (Alnitec, Cremosano, CR, Italy) and the cell suspension was gently mixed with the gas for $10 \mathrm{~min}$ to allow the full reaction of cells with the gas [86]. For S-phase cells evaluation, SEM analysis, and wound healing assay, after trypsinization, the cells were seeded on glass slides placed in multi-well microplates, let to adhere for at least $24 \mathrm{~h}$ and then submitted to gas treatment as described in [87]. For LDH and cytokine assays, $2 \times 10^{4}$ cells per 24-multi-well plate were seeded after gas treatment. At $24 \mathrm{~h}$, the medium was collected and stored at $-80^{\circ} \mathrm{C}$ until analysis.

Some fibroblast samples were pre-incubated with $1 \mu \mathrm{g} / \mathrm{mL}$ LPS for $24 \mathrm{~h}$ as previously reported $[23,88]$ in order to induce cell activation, and then processed as above.

\subsection{Cytotoxicity}

$\mathrm{LDH}$, a cytosolic enzyme released by lysed cells, was evaluated as an estimate of the cytotoxic effect of gas exposure by using the CytoTox96 nonradioactive assay (Promega, Milan, MI, Italy). Cytotoxicity rate was estimated $24 \mathrm{~h}$ after the gas treatment in both non-activated and LPS-activated fibroblasts. Aliquots of medium were collected for each condition, placed in a 96-multi-well plate, mixed with the CytoTox 96 reagent and incubated for $30 \mathrm{~min}$ at room temperature. After addition of the stop solution, the absorbance was measured at $492 \mathrm{~nm}$, and the data were corrected for culture medium background and normalized to the maximum LDH release (i.e., the one of lysed samples).

\subsection{S-Phase Evaluation}

The percentage of S-phase cells was assessed $24 \mathrm{~h}$ after treatment in both nonactivated and LPS-activated fibroblasts, as a measure of the cell proliferation rate. The cells $\left(2 \times 10^{4}\right.$ cells per $24 \mathrm{~mm} \times 24 \mathrm{~mm}$ slides $)$ were pulse-labelled with $20 \mu \mathrm{M}$ BrdU (Sigma-Aldrich, St. Louis, MO, USA) for $30 \mathrm{~min}$ at $37^{\circ} \mathrm{C}$, then fixed with $70 \%$ ethanol and incubated for $20 \mathrm{~min}$ at room temperature in $2 \mathrm{~N} \mathrm{HCl}$ to partially denature DNA; after neutralization with $0.1 \mathrm{M}$ sodium tetraborate ( $\mathrm{pH}$ 8.2) (Sigma-Aldrich) for $3 \mathrm{~min}$, samples were washed in PBS, permeabilized for $15 \mathrm{~min}$ in PBS containing $0.1 \%$ bovine serum albumin and 0.05\% Tween-20 (Sigma-Aldrich), and incubated for $1 \mathrm{~h}$ with a mouse monoclonal antibody recognizing BrdU (BD Diagnostics, Franklin Lakes, NJ, USA) diluted 1:20 in PBS. After two washes with PBS, samples were incubated for $1 \mathrm{~h}$ with an Alexa 
Fluor 488-conjugated anti-mouse secondary antibody (Molecular Probes, Invitrogen, Milan, MI, Italy), diluted 1:200. The cell samples were washed with PBS, stained for DNA with $0.1 \mu \mathrm{g} / \mathrm{mL}$ Hoechst 33342 (Abcam, Cambridge, United Kingdom) in PBS for $10 \mathrm{~min}$, and finally mounted in PBS/glycerol (1:1). The percentage of BrdU-positive cells was evaluated in 30 randomly selected fields $(40 \times)$ per experimental condition. For observation of all samples, an Olympus BX51 microscope (Olympus Italia S.r.l., Segrate, MI, Italy) equipped with a $100 \mathrm{~W}$ mercury lamp was used under the following conditions: 450-480 nm excitation filter (excf), $500 \mathrm{~nm}$ dichroic mirror (dm), and $515 \mathrm{~nm}$ barrier filter (bf) for Alexa Fluor 488; 330-385 nm excf, $400 \mathrm{~nm}$ dm, and $420 \mathrm{~nm}$ bf, for Hoechst 33342. Images were recorded with a QICAM Fast 1394 Digital Camera (QImaging, Surrey, BC, Canada) and processed with Image-Pro Plus software (Media Cybernetics, Inc., Rockville, MD, USA).

\subsection{Wound Healing Assay}

For the wound healing assay, $20 \times 10^{4}$ cells per well were seeded on $24 \mathrm{~mm} \times 24 \mathrm{~mm}$ slides. After $24 \mathrm{~h}$, when the cells were confluent, the cell monolayers were scratched with a sterile $200 \mu \mathrm{L}$ pipette tip and immediately exposed to gas treatment. To evaluate cell migration, images at $4 \times$ magnification were taken at $0 \mathrm{~h}, 2 \mathrm{~h}, 6 \mathrm{~h}$, and $24 \mathrm{~h}$ post-treatment using an inverted microscope (Leica DMIL, Leica Microsystems S.r.l., Buccinasco, MI, Italy) equipped with a camera (Optika Microscopes, Ponteranica, BG, Italy): the cell-free area was measured in a total of 12 randomly selected microscope fields per sample (4 fields in 3 independent experiments). The progressive reduction of the cell-free area was expressed as percentage, considering the value at time 0 as $100 \%$.

\subsection{Scanning Electron Microscopy}

For SEM analysis, $2 \times 10^{4}$ cells (both non-activated and LPS-activated fibroblasts) per well were seeded on round slides of $12 \mathrm{~mm}$ in diameter. After $24 \mathrm{~h}$, the cell monolayers were gas exposed. At $24 \mathrm{~h}$ after the treatment, the cells were fixed with $2.5 \%$ glutaraldehyde in PBS for $2 \mathrm{~h}$ at $4{ }^{\circ} \mathrm{C}$, washed in the same buffer, post-fixed with $1 \% \mathrm{OsO}_{4}$ at $4{ }^{\circ} \mathrm{C}$ for $1 \mathrm{~h}$ and dehydrated with graded ethanol. The samples were then treated by a critical point dryer (CPD 030, BAL- TEC AG, Balzers, Liechtenstein), mounted on metallic specimen stubs and sputter-coated with gold (MED 010, BAL- TEC AG). SEM imaging was performed by an XL30 ESEM (FEI Italia S.r.1., Milan, Italy). Using ImageJ software (NIH), the length of cell surface facing the edge of the monolayers was measured both including and excluding cell protrusions in 20 cells per sample; the ratio between the two values was then calculated in order to obtain an index of cell surface irregularity (the higher the value, the rougher the cell).

\subsection{Western Blot Analysis}

Non-activated and LPS-activated fibroblast samples were collected at 20 min post-gastreatment and immediately frozen in liquid nitrogen to be then placed at $-80{ }^{\circ} \mathrm{C}$. Proteins were extracted according to standard procedures in RIPA buffer (150 mM NaCl, $10 \mathrm{mM}$ Tris pH7.5, 1\% NP40, 1\% deoxycholate, 0.1\% SDS) supplemented with phosphatase and protease inhibitors (Sigma-Aldrich).

Samples were resolved on Tris-glycine 4-20\% gradient SDS-PAGE (BIO-RAD, Segrate, MI, Italy), blotted on PVDF membrane (BIO-RAD), and developed with ECL Western Blotting Substrate (Thermo Scientific, Rodano, MI, Italy). The following antibodies were used: anti-Nrf2 1:1000 (ab62532 Abcam) and Actin 1:5000 (ab8226 Abcam).

\subsection{Real-Time Quantitative Polymerase Chain Reaction}

RNA was extracted from non-activated and LPS-activated fibroblast samples after $24 \mathrm{~h}$ after the gas exposure by using the Qiagen RNeasy Plus mini kit (ref. 74134) (Qiagen S.r.l., Milan, Italy). cDNA was generated by SuperScript ${ }^{\mathrm{TM}}$ III Reverse Transcriptase (Invitrogen, cat. no. 18080093) (Thermo Fisher Scientific Inc., Waltham, MA, USA) and amplified at qPCR with Applied Biosystems ${ }^{\mathrm{TM}}$ SYBR ${ }^{\mathrm{TM}}$ Green PCR Master Mix (Applied 
Biosystems $^{\mathrm{TM}}$ 4309155) (Thermo Fisher Scientific Inc.) using 2 distinct sets of primers specific for human Hmox1 (primers set 1: Forw: CCTAAACTTCAGAGGGGGCG, Rev: GACAGCTGCCACATTAGGGT; primers set 2: Forw: AGTCTTCGCCCCTGTCTACT, Rev: CTTCACATAGCGCTGCATGG). The Applied Biosystems Step-One Real-Time PCR System was used for amplification (Thermo Fisher Scientific Inc.).

\subsection{IL-6 and TGF- $\beta 1$ Secretion}

The amount of IL- 6 and TGF- $\beta 1$ secreted was evaluated in the culture medium of both non-activated and LPS-activated fibroblasts $24 \mathrm{~h}$ after the gas treatment. For each sample, $4 \times 10^{5}$ cells $/ \mathrm{mL}$ were treated with gas; experiments were performed four times per sample and the medium was collected, centrifuged at $1500 \mathrm{~g}$ for $15 \mathrm{~min}$, and the supernatants were finally stored at $-80^{\circ} \mathrm{C}$. Quantitation of IL- 6 and TGF- $\beta 1$ was conducted on a Luminex Bio-Rad Bio-Plex 100 instrument (Bio-Rad Laboratories, Segrate, MI, Italy) coupled to the Bio-Plex Manager software, v6.0, which allows measuring multiple proteins in a single well. Briefly, $50 \mu \mathrm{L}$ aliquots of undiluted cell medium were put in a 96-well plate (samples were run in duplicate). Superparamagnetic microspheres (beads) conjugated with fluorophores and antibodies against IL- 6 and TGF- $\beta$ were added to the assay wells. Incubation and washing steps were performed as per manufacturer's recommendations, then the plate was loaded into the Luminex system for reading and signal quantitation.

\subsection{Statistical Analysis}

Data for each variable were presented as mean \pm standard error (SE). Statistical comparison was performed by either the Kruskal-Wallis non-parametric test (cytotoxicity; wound healing assay, cytokines) followed by the Mann-Whitney test for pairwise comparison or the one-way analysis of variance (ANOVA) test (S-phase evaluation; index of cell surface irregularity, RT-qPCR) followed by Bonferroni's post-hoc test. To RT-qPCR results, the test for linear trend was also applied. Statistical significance was set at $p \leq 0.05$.

\section{Conclusions}

Taken together, the results of the present study not only extend to fibroblasts the notion that low $\mathrm{O}_{3}$ concentrations are safe for cells, but also provide original evidence that the administration of $\mathrm{O}_{2}-\mathrm{O}_{3}$ gas mixtures induces multiple effects on fibroblasts, depending on their activation state. In sum, in non-activated fibroblasts, $\mathrm{O}_{3}$ is able to stimulate proliferation, formation of cell surface protrusions, antioxidant response, and IL- 6 and TGF- $\beta 1$ secretion, while in LPS-activated fibroblasts, $\mathrm{O}_{3}$ stimulates antioxidant response and cytokines secretion without affecting cell proliferation and motility. It is therefore evident that the low $\mathrm{O}_{3}$ concentrations used in this study induce activationlike responses in non-activated fibroblasts, whereas, in fibroblasts already activated by LPS, the gas exposure potentiates the cell protective capability. Interestingly, most of the effects observed in non-activated fibroblasts are due to the exposure to 10 or $20 \mu \mathrm{g} \mathrm{O}$, i.e., the concentrations that have been already found as optimal for safely inducing positive response in various cell models $[5-7,11,15,16]$. This perfectly agrees with the low-dose concept in the medical use of $\mathrm{O}_{3}[89,90]$, which is increasingly applied in clinical practice.

The simple in vitro model used in the present study was a suitable tool to shed light on the specific responses of fibroblasts to low $\mathrm{O}_{3}$ concentrations; however, the observed effects should be investigated in a more complex network of mutual interactions of different cells and humoral factors, as it occurs in a living organism. Based on the present findings, further in vivo studies will elucidate the contribution of fibroblasts in the response to $\mathrm{O}_{2}-\mathrm{O}_{3}$ therapy, taking into account their multiple roles in tissue repair and homeostasis; this will provide novel information to properly modulate the $\mathrm{O}_{3}$ administration protocols for specific therapeutic needs.

Supplementary Materials: The following are available online at https: / www.mdpi.com/article / 10.3390/ijms221810133/s1, Figure S1: Wound healing assay of non-activated fibroblasts, Figure S2: Wound healing assay of LPS-activated fibroblasts. 
Author Contributions: Conceptualization, O.A., G.T. and M.M.; methodology, B.C. and M.C.; investigation, B.C., M.C., M.A.L. and M.G.; writing-original draft preparation, B.C. and M.M.; writingreview and editing, O.A., G.T. and M.M.; supervision, M.M.; project administration, M.M.; funding acquisition, M.M. All authors have read and agreed to the published version of the manuscript.

Funding: This research was funded by the University of Verona (Joint Projects 2019) and by Tecnoline S.p.a. (Concordia sulla Secchia, MO, Italy).

Institutional Review Board Statement: Not applicable.

Informed Consent Statement: Not applicable.

Data Availability Statement: Not applicable.

Acknowledgments: The authors thank Paolo Bernardi for skillful technical support at the scanning electron microscope.

Conflicts of Interest: The authors declare no conflict of interest. The funders had no role in the design of the study; in the collection, analyses, or interpretation of data; in the writing of the manuscript, or in the decision to publish the results.

\section{References}

1. Re, L.; Mawsouf, M.N.; Menéndez, S.; León, O.S.; Sánchez, G.M.; Hernández, F. Ozone therapy: Clinical and basic evidence of its therapeutic potential. Arch. Med. Res. 2008, 39, 17-26. [CrossRef]

2. Elvis, A.M.; Ekta, J.S. Ozone therapy: A clinical review. J. Nat. Sci. Biol. Med. 2011, 2, 66-70. [CrossRef]

3. Bocci, V. How a calculated oxidative stress can yield multiple therapeutic effects. Free Radic. Res. 2012, 46, 1068-1075. [CrossRef]

4. Scassellati, C.; Galoforo, A.C.; Bonvicini, C.; Esposito, C.; Ricevuti, G. Ozone: A natural bioactive molecule with antioxidant property as potential new strategy in aging and in neurodegenerative disorders. Ageing Res. Rev. 2020, 63, 101138. [CrossRef] [PubMed]

5. Galiè, M.; Costanzo, M.; Nodari, A.; Boschi, F.; Calderan, L.; Mannucci, S.; Covi, V.; Tabaracci, G.; Malatesta, M. Mild ozonisation activates antioxidant cell response by the Keap1/Nrf2 dependent pathway. Free. Radic. Biol. Med. 2018, 124, 114-121. [CrossRef]

6. Cisterna, B.; Costanzo, M.; Nodari, A.; Galiè, M.; Zanzoni, S.; Bernardi, P.; Covi, V.; Tabaracci, G.; Malatesta, M. Ozone activates the Nrf2 pathway and improves preservation of explanted adipose tissue in vitro. Antioxidants 2020, 9, 989. [CrossRef] [PubMed]

7. Cappellozza, E.; Costanzo, M.; Calderan, L.; Galiè, M.; Angelini, O.; Tabaracci, G.; Malatesta, M. Low ozone concentrations affect the structural and functional features of jurkat T cells. Processes 2021, 9, 1030. [CrossRef]

8. Sagai, M.; Bocci, V. Mechanisms of action involved in ozone therapy: Is healing induced via a mild oxidative stress? Med. Gas Res. 2011, 1, 29. [CrossRef] [PubMed]

9. Galiè, M.; Covi, V.; Tabaracci, G.; Malatesta, M. The role of Nrf2 in the antioxidant cellular response to medical ozone exposure. Int. J. Mol. Sci. 2019, 20, 4009. [CrossRef]

10. Goldman, M. Cancer risk of low-level exposure. Science 1996, 271, 1821-1822. [CrossRef]

11. Costanzo, M.; Boschi, F.; Carton, F.; Conti, G.; Covi, V.; Tabaracci, G.; Sbarbati, A.; Malatesta, M. Low ozone concentrations promote adipogenesis in human adipose-derived adult stem cells. Eur. J. Histochem. 2018, 62, 2969. [CrossRef] [PubMed]

12. Koliaraki, V.; Prados, A.; Armaka, M.; Kollias, G. The mesenchymal context in inflammation, immunity and cancer. Nat. Immunol. 2020, 21, 974-982. [CrossRef] [PubMed]

13. Buechler, M.B.; Pradhan, R.N.; Krishnamurty, A.T.; Cox, C.; Calviello, A.K.; Wang, A.W.; Yang, Y.A.; Tam, L.; Caothien, R.; Roose-Girma, M.; et al. Cross-tissue organization of the fibroblast lineage. Nat. Cell Biol. 2021, 593, 575-579. [CrossRef]

14. Hinz, B.; Lagares, D. Evasion of apoptosis by myofibroblasts: A hallmark of fibrotic diseases. Nat. Rev. Rheumatol. 2020, 16, 11-31. [CrossRef]

15. Costanzo, M.; Cisterna, B.; Vella, A.; Cestari, T.; Covi, V.; Tabaracci, G.; Malatesta, M. Low ozone concentrations stimulate cytoskeletal organization, mitochondrial activity and nuclear transcription. Eur. J. Histochem. 2015, 59, 2515. [CrossRef]

16. Scassellati, C.; Costanzo, M.; Cisterna, B.; Nodari, A.; Galiè, M.; Cattaneo, A.; Covi, V.; Tabaracci, G.; Bonvicini, C.; Malatesta, M. Effects of mild ozonisation on gene expression and nuclear domains organization in vitro. Toxicol. In Vitro 2017, 44, 100-110. [CrossRef]

17. Zhang, H.-Y.; Phan, S. Inhibition of myofibroblast apoptosis by transforming growth factor $\beta 1$. Am. J. Respir. Cell Mol. Biol. 1999, 21, 658-665. [CrossRef] [PubMed]

18. Xie, Z.; Paras, C.B.; Weng, H.; Punnakitikashem, P.; Su, L.-C.; Vu, K.; Tang, L.; Yang, J.; Nguyen, K.T. Dual growth factor releasing multi-functional nanofibers for wound healing. Acta Biomater. 2013, 9, 9351-9359. [CrossRef]

19. Zhang, X.; Kang, X.; Jin, L.; Bai, J.; Liu, W.; Wang, Z. Stimulation of wound healing using bioinspired hydrogels with basic fibroblast growth factor (bFGF). Int. J. Nanomed. 2018, 13, 3897-3906. [CrossRef] [PubMed]

20. Cowin, A.J.; Hatzirodos, N.; Teusner, J.T.; Belford, D.A. Differential effect of wounding on actin and its associated proteins, paxillin and gelsolin, in fetal skin explants. J. Investig. Dermatol. 2003, 120, 1118-1129. [CrossRef] 
21. Lees, J.; Ching, Y.W.; Adams, D.; Bach, C.T.; Samuel, M.; Kee, A.J.; Hardeman, E.C.; Gunning, P.; Cowin, A.; O’Neill, G.M. Tropomyosin regulates cell migration during skin wound healing. J. Investig. Dermatol. 2013, 133, 1330-1339. [CrossRef]

22. Zhang, J.; Wu, L.; Qu, J.-M. Inhibited proliferation of human lung fibroblasts by LPS is through IL-6 and IL-8 release. Cytokine 2011, 54, 289-295. [CrossRef]

23. Yang, H.; Hu, C.; Li, F.; Liang, L.; Liu, L. Effect of lipopolysaccharide on the biological characteristics of human skin fibroblasts and hypertrophic scar tissue formation. IUBMB Life 2013, 65, 526-532. [CrossRef] [PubMed]

24. Rodemann, H.P.; Müller, G.A. Characterization of human renal fibroblasts in health and disease: II. In vitro growth, differentiation, and collagen synthesis of fibroblasts from kidneys with interstitial fibrosis. Am. J. Kidney Dis. 1991, 17, 684-686. [CrossRef]

25. Brown, R.A.; Prajapati, R.; McGrouther, D.A.; Yannas, I.V.; Eastwood, M. Tensional homeostasis in dermal fibroblasts: Me-chanical responses to mechanical loading in three-dimensional substrates. J. Cell Physiol. 1998, 175, 323-332. [CrossRef]

26. Simian, M.; Hirai, Y.; Navre, M.; Werb, Z.; Lochter, A.; Bissell, M.J. The interplay of matrix metalloproteinases, morphogens and growth factors is necessary for branching of mammary epithelial cells. Development 2001, 128, 3117-3131. [CrossRef]

27. Fraley, S.; Feng, Y.; Krishnamurthy, R.; Kim, D.-H.; Celedon, A.; Longmore, G.D.; Wirtz, D. A distinctive role for focal adhesion proteins in three-dimensional cell motility. Nat. Cell Biol. 2010, 12, 598-604. [CrossRef] [PubMed]

28. Padhi, A.; Singh, K.; Franco-Barraza, J.; Marston, D.J.; Cukierman, E.; Hahn, K.M.; Kapania, R.K.; Nain, A.S. Force-exerting perpendicular lateral protrusions in fibroblastic cell contraction. Commun. Biol. 2020, 3, 1-11. [CrossRef]

29. Sakai, J.; Li, J.; Subramanian, K.K.; Mondal, S.; Bajrami, B.; Hattori, H.; Jia, Y.; Dickinson, B.C.; Zhong, J.; Ye, K.; et al. Reactive oxygen species-induced actin glutathionylation controls actin dynamics in neutrophils. Immunity 2012, 37, 1037-1049. [CrossRef]

30. Taulet, N.; Delorme-Walker, V.D.; DerMardirossian, C. Reactive oxygen species regulate protrusion efficiency by controlling actin dynamics. PLoS ONE 2012, 7, e41342. [CrossRef]

31. Muliyil, S.; Narasimha, M. Mitochondrial ROS regulates cytoskeletal and mitochondrial remodeling to tune cell and tissue dynamics in a model for wound healing. Dev. Cell 2014, 28, 239-252. [CrossRef]

32. Huang, C.-H.; Tang, M.; Shi, C.; Iglesias, P.A.; Devreotes, P.N. An excitable signal integrator couples to an idling cytoskeletal oscillator to drive cell migration. Nat. Cell Biol. 2013, 15, 1307-1316. [CrossRef]

33. Gardel, M.L.; Schneider, I.; Aratyn-Schaus, Y.; Waterman, C.M. Mechanical integration of actin and adhesion dynamics in cell migration. Annu. Rev. Cell Dev. Biol. 2010, 26, 315-333. [CrossRef]

34. Costanzo, M.; Romeo, A.; Cisterna, B.; Calderan, L.; Bernardi, P.; Covi, V.; Tabaracci, G.; Malatesta, M. Ozone at low concentrations does not affect motility and proliferation of cancer cells in vitro. Eur. J. Histochem. 2020, 64, 3119. [CrossRef]

35. Bhattarai, G.; Poudel, S.B.; Kook, S.-H.; Lee, J.-C. Resveratrol prevents alveolar bone loss in an experimental rat model of periodontitis. Acta Biomater. 2016, 29, 398-408. [CrossRef] [PubMed]

36. Gasparrini, M.; Giampieri, F.; Forbes-Hernandez, T.Y.; Afrin, S.; Cianciosi, D.; Reboredo-Rodriguez, P.; Varela-López, A.; Zhang, J.; Quiles, J.L.; Mezzetti, B.; et al. Strawberry extracts efficiently counteract inflammatory stress induced by the endotoxin lipopolysaccharide in human dermal fibroblast. Food Chem. Toxicol. 2018, 114, 128-140. [CrossRef] [PubMed]

37. Huang, C.; Zhang, C.; Yang, P.; Chao, R.; Yue, Z.; Li, C.; Guo, J.; Li, M. Eldecalcitol inhibits LPS-induced NLRP3 inflammasomedependent pyroptosis in human gingival fibroblasts by activating the Nrf2/HO-1 signaling pathway. Drug Des. Dev. Ther. 2020, 14, 4901-4913. [CrossRef] [PubMed]

38. Re, L.; Martínez-Sánchez, G.; Bordicchia, M.; Malcangi, G.; Pocognoli, A.; Morales-Segura, M.A.; Rothchild, J.; Rojas, A. Is ozone pre-conditioning effect linked to Nrf2/EpRE activation pathway in vivo? A preliminary result. Eur. J. Pharmacol. 2014, 742, 158-162. [CrossRef] [PubMed]

39. Yu, G.; Liu, X.; Chen, Z.; Chen, H.; Wang, L.; Wang, Z.; Qiu, T.; Weng, X. Ozone therapy could attenuate tubulointerstitial injury in adenine-induced CKD rats by mediating Nrf2 and NF-kappaB. Iran. J. Basic Med. Sci. 2016, 19, 1136-1143. [PubMed]

40. Delgado-Roche, L.; Riera-Romo, M.; Mesta, F.; Hernández-Matos, Y.; Barrios, J.M.; Martínez-Sánchez, G.; Al-Dalaien, S.M. Medical ozone promotes Nrf2 phosphorylation reducing oxidative stress and pro-inflammatory cytokines in multiple sclerosis patients. Eur. J. Pharmacol. 2017, 811, 148-154. [CrossRef]

41. Meng, W.; Xu, Y.; Li, D.; Zhu, E.; Deng, L.; Liu, Z.; Zhang, G.; Liu, H. Ozone protects rat heart against ischemia-reperfusion injury: A role for oxidative preconditioning in attenuating mitochondrial injury. Biomed. Pharmacother. 2017, 88, 1090-1097. [CrossRef]

42. Siniscalco, D.; Trotta, M.C.; Brigida, A.L.; Maisto, R.; Luongo, M.; Ferraraccio, F.; D'Amico, M.; di Filippo, C. Intraperitoneal administration of oxygen/ozone to rats reduces the pancreatic damage induced by streptozotocin. Biology 2018, 7, 10. [CrossRef]

43. Wang, Z.; Zhang, A.; Meng, W.; Wang, T.; Li, D.; Liu, Z.; Liu, H. Ozone protects the rat lung from ischemia-reperfusion injury by attenuating NLRP3-mediated inflammation, enhancing Nrf2 antioxidant activity and inhibiting apoptosis. Eur. J. Pharmacol. 2018, 835, 82-93. [CrossRef]

44. Simonetti, V.; Quagliariello, V.; Franzini, M.; Iaffaioli, R.V.; Maurea, N.; Valdenassi, L. Ozone exerts cytoprotective and antiinflammatory effects in cardiomyocytes and skin fibroblasts after incubation with doxorubicin. Evid. Based Complement. Altern. Med. 2019, 2019, 1-9. [CrossRef] [PubMed]

45. Leewananthawet, A.; Arakawa, S.; Okano, T.; Kinoshita, R.D.; Ashida, H.; Izumi, Y.; Suzuki, T. Ozone ultrafine bubble water induces the cellular signaling involved in oxidative stress responses in human periodontal ligament fibroblasts. Sci. Technol. Adv. Mater. 2019, 20, 590-599. [CrossRef] [PubMed]

46. Apte, R.N. Mechanisms of cytokine production by fibroblasts-implications for normal connective tissue homeostasis and pathological conditions. Folia Microbiol. 1995, 40, 392-404. [CrossRef] 
47. Bengtsson, T.; Zhang, B.; Selegård, R.; Wiman, E.; Aili, D.; Khalaf, H. Dual action of bacteriocin PLNC8 $\alpha \beta$ through inhibition of Porphyromonas gingivalis infection and promotion of cell proliferation. Pathog. Dis. 2017, 75, 064. [CrossRef] [PubMed]

48. Maita, E.; Sato, M.; Yamaki, K. Effect of tranilast on matrix metalloproteinase-1 secretion from human gingival fibroblasts in vitro. J. Periodontol. 2004, 75, 1054-1060. [CrossRef]

49. Scheller, J.; Chalaris, A.; Schmidt-Arras, D.; Rose-John, S. The pro- and anti-inflammatory properties of the cytokine interleukin-6. Biochim. Biophys. Acta 2011, 1813, 878-888. [CrossRef]

50. Van Oers, M.H.; van der Heyden, A.A.; Aarden, L.A. Interleukin 6 (IL-6) in serum and urine of renal transplant recipients. Clin. Exp. Immunol. 1988, 71, 314-319. [PubMed]

51. Fong, Y.; Moldawer, L.L.; Marano, M.; Wei, H.; Tatter, S.; Clarick, R.H.; Santhanam, U.; Sherris, D.; May, L.T.; Sehgal, P.B Endotoxemia elicits increased circulating beta 2-IFN/IL-6 in man. J. Immunol. 1989, 142, 2321-2324.

52. Helfgott, D.C.; Tatter, S.; Santhanam, U.; Clarick, R.H.; Bhardwaj, N.; May, L.T.; Sehgal, P.B. Multiple forms of IFN-beta 2/IL-6 in serum and body fluids during acute bacterial infection. J. Immunol. 1989, 142, 948-953.

53. Lin, Z.-Q.; Kondo, T.; Ishida, Y.; Takayasu, T.; Mukaida, N. Essential involvement of IL-6 in the skin wound-healing process as evidenced by delayed wound healing in IL-6-deficient mice. J. Leukoc. Biol. 2003, 73, 713-721. [CrossRef] [PubMed]

54. Baum, C.L.; Arpey, C.J. Normal cutaneous wound healing: Clinical correlation with cellular and molecular events. Dermatol. Surg. 2006, 31, 674-686. [CrossRef] [PubMed]

55. Basso, F.G.; Soares, D.G.; Pansani, T.N.; Cardoso, L.M.; Scheffel, D.; de Souza Costa, C.A.; Hebling, J. Proliferation, migration, and expression of oral-mucosal-healing-related genes by oral fibroblasts receiving low-level laser therapy after inflammatory cytokines challenge. Lasers Surg. Med. 2016, 48, 1006-1014. [CrossRef] [PubMed]

56. Saglam, M.; Köseoglu, S.; Pekbagriyanik, T.; Savran, L.; Enhos, S. Effects of high powerpulsed Nd: YAG laser irradiation on the release of transforming growth factor-beta (TGF- $\beta$ ) and vascular endothelial growth factor (VEGF) from human gingival fibroblasts. J. Cosmet. Laser Ther. 2017, 19, 469-474. [CrossRef]

57. Valacchi, G.; Lim, Y.; Ms, G.B.; Miracco, C.; Zanardi, I.; Bocci, V.; Travagli, V. Ozonated sesame oil enhances cutaneous wound healing in SKH1 mice. Wound Repair Regen. 2010, 19, 107-115. [CrossRef]

58. Martínez-Sánchez, G.; Al-Dalain, S.M.; Menéndez, S.; Re, L.; Giuliani, A.; Candelario-Jalil, E.; Álvarez, H.; Fernández-Montequín, J.I.; León, O.S. Therapeutic efficacy of ozone in patients with diabetic foot. Eur. J. Pharmacol. 2005, 523, 151-161. [CrossRef] [PubMed]

59. Taşdemir, Z.; Alkan, B.A.; Albayrak, H. Effects of ozone therapy on the early healing period of deepithelialized gingival grafts: A randomized placebo-controlled clinical trial. J. Periodontol. 2016, 87, 663-671. [CrossRef]

60. Karakaya, E.; Akdur, A.; Ayvazoğlu Soy, E.; Araz, C.; Ok Atilgan, A.; Özturan Özer, E.; Şençelikel, T.; Haberal, M. Effect of subcutaneous topical ozone therapy on second-degree burn wounds in rats: An experimental study. J. Burn. Care Res. 2021, 16, 110. [CrossRef] [PubMed]

61. Chang, J.D.S.; Lu, H.-S.; Chang, Y.-F.; Wang, D. Ameliorative effect of ozone on cytokine production in mice injected with human rheumatoid arthritis synovial fibroblast cells. Rheumatol. Int. 2004, 26, 142-151. [CrossRef] [PubMed]

62. Wahl, S.M.; Hunt, D.A.; Wakefield, L.M.; McCartney-Francis, N.; Roberts, A.B.; Sporn, M.B. Transforming growth factor type beta induces monocyte chemotaxis and growth factor production. Proc. Natl. Acad. Sci. USA 1987, 84, 5788-5792. [CrossRef] [PubMed]

63. Ignotz, R.A.; Endo, T.; Massagué, J. Regulation of fibronectin and type I collagen mRNA levels by transforming growth factor-beta. J. Biol. Chem. 1987, 262, 6443-6446. [CrossRef]

64. Varga, J.; Rosenbloom, J.; Jimenez, S. Transforming growth factor $\beta$ (TGF $\beta$ ) causes a persistent increase in steady-state amounts of type I and type III collagen and fibronectin mRNAs in normal human dermal fibroblasts. Biochem. J. 1987, 247, 597-604. [CrossRef]

65. Peltonen, J.; Kähäri, L.; Jaakkola, S.; Kähäri, V.-M.; Varga, J.; Uitto, J.; Jimenez, S.A. Evaluation of transforming growth factor $\beta$ and type I procollagen gene expression in fibrotic skin disease by in situ hybridization. J. Investig. Dermatol. 1990, 94, 365-371. [CrossRef]

66. Grässel, S.; Tan, E.M.; Timpl, R.; Chu, M.-L. Collagen type XVI expression is modulated by basic fibroblast growth factor and transforming growth factor- $\beta$. FEBS Lett. 1998, 436, 197-201. [CrossRef]

67. Kissin, E.Y.; Lemaire, R.; Korn, J.H.; Lafyatis, R. Transforming growth factor $\beta$ induces fibroblast fibrillin- 1 matrix formation. Arthritis Rheum. 2002, 46, 3000-3009. [CrossRef] [PubMed]

68. Wang, X.; Abraham, S.; McKenzie, J.A.G.; Jeffs, N.; Swire, M.; Tripathi, V.B.; Luhmann, U.F.; Lange, C.A.K.; Zhai, Z.; Arthur, H.; et al. LRG1 promotes angiogenesis by modulating endothelial TGF- $\beta$ signalling. Nat. Cell Biol. 2013, 499, 306-311. [CrossRef] [PubMed]

69. Zhao, M.; Hu, Y.; Jin, J.; Yu, Y.; Zhang, S.; Cao, J.; Zhai, Y.; Wei, R.; Shou, J.; Cai, W.; et al. Interleukin 37 promotes angiogenesis through TGF- $\beta$ signaling. Sci. Rep. 2017, 7, 6113. [CrossRef] [PubMed]

70. Miscianinov, V.; Martello, A.; Rose, L.; Parish, E.; Cathcart, B.; Mitić, T.; Gray, G.A.; Meloni, M.; Zen, A.A.H.; Caporali, A. MicroRNA-148b targets the TGF- $\beta$ pathway to regulate angiogenesis and endothelial-to-mesenchymal transition during skin wound healing. Mol. Ther. 2018, 26, 1996-2007. [CrossRef] [PubMed]

71. Baricos, W.H.; Cortez, S.L.; Deboisblanc, M.; Xin, S. Transforming growth factor- $\beta$ is a potent inhibitor of extracellular matrix degradation by cultured human mesangial cells. J. Am. Soc. Nephrol. 1999, 10, 790-795. [CrossRef] [PubMed] 
72. Silverio-Ruiz, K.G.; Martinez, A.E.T.; Garlet, G.P.; Barbosa, C.F.; Silva, J.S.; Cicarelli, R.M.B.; Valentini, S.R.; Abi-Rached, R.S.G.; Junior, C.R. Opposite effects of bFGF and TGF- $\beta$ on collagen metabolism by human periodontal ligament fibroblasts. Cytokine 2007, 39, 130-137. [CrossRef]

73. Safavi, S.M.; Kazemi, B.; Esmaeili, M.; Fallah, A.; Modarresi, A.; Mir, M. Effects of low-level He-Ne laser irradiation on the gene expression of IL-1 $\beta$, TNF- $\alpha$, IFN- $\gamma$, TGF- $\beta$, bFGF, and PDGF in rat's gingiva. Lasers Med Sci. 2007, 23, 331-335. [CrossRef]

74. Meran, S.; Thomas, D.W.; Stephens, P.; Enoch, S.; Martin, J.; Steadman, R.; Phillips, A.O. Hyaluronan facilitates transforming growth factor- $\beta 1$-mediated fibroblast proliferation. J. Biol. Chem. 2008, 283, 6530-6545. [CrossRef]

75. Khalil, N.; Xu, Y.D.; O'Connor, R.; Duronio, V. Proliferation of pulmonary interstitial fibroblasts is mediated by transforming growth factor- $\beta 1$-induced release of extracellular fibroblast growth factor-2 and phosphorylation of p38 MAPK and JNK. J. Biol. Chem. 2005, 280, 43000-43009. [CrossRef]

76. Cui, Y.; Xin, H.; Tao, Y.; Mei, L.; Wang, Z. Arenaria kansuensis attenuates pulmonary fibrosis in mice via the activation of Nrf2 pathway and the inhibition of NF-kB/TGF -beta1/Smad2/3 pathway. Phytother. Res. 2021, 35, 974-986. [CrossRef]

77. Oh, C.J.; Kim, J.-Y.; Min, A.-K.; Park, K.-G.; Harris, R.A.; Kim, H.-J.; Lee, I.-K. Sulforaphane attenuates hepatic fibrosis via NF-E2-related factor 2-mediated inhibition of transforming growth factor- $\beta /$ Smad signaling. Free. Radic. Biol. Med. 2012, 52, 671-682. [CrossRef] [PubMed]

78. Oh, C.J.; Kim, J.-Y.; Choi, Y.-K.; Kim, H.-J.; Jeong, J.-Y.; Bae, K.-H.; Park, K.-G.; Lee, I.-K. Dimethylfumarate attenuates renal fibrosis via nf-e2-related factor 2-mediated inhibition of transforming growth factor- $\beta /$ Smad signaling. PLoS ONE 2012, 7, e45870. [CrossRef]

79. Kim, H.S.; Noh, S.U.; Han, Y.W.; Kim, K.M.; Kang, H.; Kim, H.O.; Park, Y.M. Therapeutic effects of topical application of ozone on acute cutaneous wound healing. J. Korean Med. Sci. 2009, 24, 368-374. [CrossRef]

80. Xiao, W.; Tang, H.; Wu, M.; Liao, Y.; Li, K.; Li, L.; Xu, X. Ozone oil promotes wound healing by increasing the migration of fibroblasts via PI3K/Akt/mTOR signaling pathway. Biosci. Rep. 2017, 37, 20170658. [CrossRef] [PubMed]

81. Poulalhon, N.; Farge, D.; Roos, N.; Tacheau, C.; Neuzillet, C.; Michel, L.; Mauviel, A.; Verrecchia, F. Modulation of collagen and mmp-1 gene expression in fibroblasts by the immunosuppressive drug rapamycin. J. Biol. Chem. 2006, 281, 33045-33052. [CrossRef]

82. Roos, N.; Poulalhon, N.; Farge, D.; Madelaine, I.; Mauviel, A.; Verrecchia, F. In vitro evidence for a direct antifibrotic role of the immunosuppressive drug mycophenolate mofetil. J. Pharmacol. Exp. Ther. 2007, 321, 583-589. [CrossRef] [PubMed]

83. Hovest, M.G.; Brüggenolte, N.; Hosseini, K.S.; Krieg, T.; Herrmann, G. Senescence of human fibroblasts after psoralen photoactivation is mediated by ATR kinase and persistent DNA damage foci at telomeres. Mol. Biol. Cell 2006, 17, $1758-1767$. [CrossRef]

84. Neutelings, T.; Lambert, C.A.; Nusgens, B.V.; Colige, A.C. Effects of mild cold shock $\left(25^{\circ} \mathrm{C}\right)$ followed by warming up at $37^{\circ} \mathrm{C}$ on the cellular stress response. PLoS ONE 2013, 8, e69687. [CrossRef]

85. Nunes, R.R.; Costa, M.D.S.; Santos, B.D.R.; da Fonseca, A.L.; Ferreira, L.S.; Chagas, R.C.R.; da Silva, A.M.; Varotti, F.D.P.; Taranto, A.G. Successful application of virtual screening and molecular dynamics simulations against antimalarial molecular targets. Memórias Inst. Oswaldo Cruz 2016, 111, 721-730. [CrossRef] [PubMed]

86. Larini, A.; Bianchi, L.; Bocci, V. The ozone tolerance: I) Enhancement of antioxidant enzymes is ozone dose-dependent in Jurkat cells. Free Radic. Res. 2003, 37, 1163-1168. [CrossRef]

87. Costanzo, M.; Cisterna, B.; Covi, V.; Tabaracci, G.; Malatesta, M. An easy and inexpensive method to expose adhering cultured cells to ozonization. Microscopie 2015, 23, 46-52. Available online: https://www.pagepressjournals.org/index.php/microscopie/ article/view/5164/4554 (accessed on 28 August 2021).

88. Li, X.-P.; Liu, P.; Li, Y.-F.; Zhang, G.-L.; Zeng, D.-S.; Liu, D.-L. LPS induces activation of the TLR4 pathway in fibroblasts and promotes skin scar formation through collagen I and TGF- $\beta$ in skin lesions. Int. J. Clin. Exp. Pathol. 2019, 12, $2121-2129$.

89. Viebahn-Hänsler, R.; Fernández, O.S.L.; Fahmy, Z. Ozone in medicine: The low-dose ozone concept-Guidelines and treatment strategies. Ozone Sci. Eng. 2012, 34, 408-424. [CrossRef]

90. Viebahn-Haensler, R.; Fernández, O.L. Ozone in medicine. The low-dose ozone concept and its basic biochemical mechanisms of action in chronic inflammatory diseases. Int. J. Mol. Sci. 2021, 22, 7890. [CrossRef] 